\title{
BINGKAI PEMBERITAAN PEREMPUAN DI MAJALAH TEMPO EDISI KHUSUS “PEREMPUAN-PEREMPUAN PENEMBUS BATAS"
}

\author{
Natalia Mandiriani ${ }^{1 *}$, Fanny Lesmana ${ }^{2}$, Desi Yoanita ${ }^{3}$ \\ 1,2,3 Program Studi Ilmu Komunikasi, Fakultas Ilmu Komunikasi, Universitas Kristen Petra Surabaya \\ Jl. Siwalankerto 121 - 131, Surabaya 60236, INDONESIA \\ * Penulis korespondensi; Email: nataliamandiriani@gmail.com
}

\begin{abstract}
ABSTRAK
Fenomena perempuan yang bekerja di bidang publik biasanya mendapat stereotipe yang merugikan. Pandangan budaya ketimuran menempatkan perempuan seharusnya berada di wilayah domestik untuk mengurus rumah tangga, melayani suami dan merawat anak. Pandangan yang merugikan perempuan ini terjadi salah satunya karena media yang mengukuhkannya. Majalah Tempo pada April 2016 mengeluarkan sebuah edisi khusus yang membahas mengenai perempuan yang bekerja. Melalui analisis framing Pan\&Kosicki, ditemukan bahwa Majalah Tempo membingkai perempuan dari pandangan feminisme liberal, dengan menonjolkan perempuan sebagai agen perubahan, sosok pejuang, membutuhkan dukungan, memiliki kemampuan bekerja yang baik, dan terlibat dalam kemajuan bangsa.
\end{abstract}

Kata kunci: Perempuan bekerja, bingkai, berita, Zhong Dang Pan dan Gerald M. Kosicki, Majalah Tempo

\begin{abstract}
The phenomenon of women working in public sector usually gets harmful stereotypes. The view of eastern culture places women should be in the domestic area to take care of the household, serve their husbands and care for children. This view that is detrimlental to women is one of them due to the media that confirmed it. Tempo Magazine in April 2016 issued a special edition that discussed women working. Through the analysis of framing Pan \& Kosicki, it was found that Tempo Magazine framed women from the perspective of liberal feminism, by highlighting women as agents of change, figures of warriors, needing support, having the ability to work well, and being involved in the nation's progress.
\end{abstract}

Keywords: Working women, frame, news, Zhong Dang Pan dan Gerald M. Kosicki, Tempo Magazine.

\section{PENDAHULUAN}

Perempuan karier masih menjadi dilema bagi perempuan Indonesia. Berbagai mitos mengenai perempuan nyatanya masih melekat erat dengan budaya-budaya yang ada di Indonesia. Masalah isu gender juga masih sering diperdebatkan, sikap masyarakat terhadap perempuan yang bekerja di sektor publik masih tetap berada dalam kotak stereotipe. Bahkan peran yang dimainkan perempuan pun masih dalam dominasi kaum laki-laki (Murniati, 2004, 59).

Dalam bukunya, Murniati juga menuliskan mengenai peran gender (2004, p. 59-60) yaitu gender bernuansa psikologis, sosiologis dan budaya. Gender merupakan perolehan dari proses belajar dan proses sosialisasi melalui kebudayaan masyarakat yang bersangkutan. Gender membedakan manusia laki-laki dan perempuan secara sosial, mengacu pada unsur emosional, kejiwaan, dan sosial (buatan manusia). Sedangkan kodrat, sesuatu yang alami dinamakan seks "kenyataan biologis" seperti kodrat perempuan adalah melahirkan, dan menyusui, sedangkan pria tidak dapat melakukan hal tersebut.
Dalam sejarah umat manusia, derajat kaum perempuan selalu berada di bawah kaum laki-laki. Ini sudah menjadi pengetahuan umum yang tidak diperdebatkan lagi. Seorang penulis, Ivan Illich, berpendapat bahwa penindasan terhadap perempuan belum pernah separah seperti dalam zaman pembangunan. Meski laki-laki juga mengalami penindasan dan menjadi korban akibat proyek besar-besaran dalam sejarah dunia mutakhir itu, perempuan lebih parah terkena dampaknya (Heryanto, 1998, p. 36-37).

Hingga kini di abad ke-21, apresiasi terhadap perempuan profesional masih saja berada dalam stereotip yang memprihatinkan. Terlebih jika peran perempuan berada di belakang laki-laki, atau hanya sebagai pembantu. Dalam konstruksi sosial, posisi pembantu berada dalam posisi subordinat. Misalnya saja pekerjaan seorang sekretaris, yang menjadi pembantu dari atasannya. Ia berada dalam posisi subordinat, profesional namun berada di belakang bayang-bayang laki-laki yang menjadi atasannya. Akibatnya, perempuan profesional terkena dampak stereotip yang dilekatkan pada label sebagai kualifikasi. Akibat lebih jauhnya, nilai hakikat atau nilai dasar munculnya 
pekerjaan itu menjadi kabur, bahkan hilang (Murniati, 2004, p. 77-78).

Dalam buku Wanita dan Media, sebuah artikel yang ditulis oleh Marwah Ibrahim mengungkap bahwa potret diri perempuan di media massa, dalam literatur, surat kabar atau majalah, film, televisi, iklan, dan buku-buku masih memperlihatkan stereotip yang merugikan : perempuan pasif, tergantung pada lakilaki, didominasi, menerima keputusan yang dibuat oleh laki-laki dan terutama melihat dirinya sebagai simbol seks (Ibrahim, 1998, 107). Nyatanya sejak dahulu hingga sekarang, citra perempuan sebagai makhluk tertindas di bawah kendali laki-laki masih belum banyak mengalami perubahan. Berbagai pergerakan yang telah dilakukan perempuan juga tidak mengalami apresiasi.

Bagi perempuan yang memilih untuk masuk ke ruang publik dan menjadi pekerja profesional justru mendapatkan stereotip yang negatif dari pandangan masyarakat. Media yang seharusnya berperan sebagai wahana pengembangan kebudayaan, bukan saja dalam pengertian pengembangan bentuk seni dan simbol, tetapi juga dalam pengertian pengembangan tata-cara, mode, gaya hidup dan norma-norma (McQuail, 1987, p. 3) masih belum mampu atau bahkan tidak melihat posisi perempuan dalam ketimpangan relasi seperti yang telah dijelaskan.

Dalam hakikatnya, media dan pers adalah agen konstruksi dari fakta atau peristiwa. Kebenaran dari suatu fakta bersifat relatif berdasarkan konteks tertentu. Lewat berbagai instrumen yang dimilikinya, media ikut membentuk realitas yang tersaji dalam pemberitaan (Eryanto, 2007, p. 22-23). Secara implisit, dari sudut pandang konstruksionis, berita bersifat subjektif dan merupakan konstruksi atas realitas. Opini tidak dapat dihilangkan dalam berita karena ketika meliput, wartawan melihat dengan perspektif dan pertimbangan subjektif (Eryanto, 2007, 27). Ditambah lagi dengan ideologi masing-masing media yang dipengaruhi dari berbagai faktor, mulai dari pemilik modal, hingga kondisi sosial budaya masyarakat.

Majalah Tempo, pada April 2016 menulis sebuah berita edisi khusus mengenai perempuan. Dengan judul "Perempuan-Perempuan Penembus Batas", Majalah Tempo merangkum berbagai profesi dari perempuan-perempuan di Indonesia dalam satu rangkaian. Edisi tersebut berisi mengenai 45 orang perem- puan yang memiliki profesi. Lead atau teras berita edisi tersebut tertulis, "Empat puluh lima perempuan pilihan ini menunjukkan perjuangan di sejumlah bidang yang sering kali patriarkis. Mengambil jalan berisiko, terjal, dan sepi."

Sepuluh kisah dari 45 cerita tersebut menjadi laporan utama yang dikupas lebih mendalam. Tulisan dari 10 profil tersebut mendapat porsi halaman lebih banyak, gambar lebih banyak, dan kisah lebih lengkap dibanding yang lain. Kisah-kisah tersebut meliputi bidang keilmuan, seni dan budaya, kreatif dan entrepreneur, hobi dan olahraga, pendidikan, kesehatan, teknologi informasi, penegakan hukum, dan lingkungan. Tentunya dengan pengkhususan pemberitaan mengenai perempuan, yakni penulisan edisi khusus akan memengaruhi framing dari berita mengenai perempuan di Majalah Tempo dibandingkan dengan media lain yang memiliki pemberitaan mengenai perempuan.

Dengan menggunakan teknik analisis framing, peneliti hendak meneliti bagaimana Majalah Tempo melakukan pembingkaian terhadap sosok-sosok perempuan yang memiliki pekerjaan yang digambarkan patriarki. Dengan metode analisis framing, peneliti dapat mengetahui bagaimana wartawan dan Majalah Tempo mengkonstruksikan pemberitaan sosok perempuan-perempuan bekerja. Framing adalah pendekatan untuk melihat bagaimana realitas dibentuk dan dikonstruksi oleh media. Hasil akhirnya adalah adanya bagian tertentu dari realitas yang lebih menonjol dan lebih mudah dikenal. Singkatnya, framing adalah sebuah cara bagaimana peristiwa disajikan oleh media dengan menyeleksi, menghubungkan dan menonjolkan peristiwa sehingga makna dari peristiwa lebih mudah menyentuh dan diingat oleh khalayak (Eriyanto, 2007, pp. 66-67). Metode penelitian yang digunakan adalah model framing milik Pan\&Kosicki yang mempunyai empat struktur yaitu sintaksis, skrip, tematik dan retoris. Rumusan masalah yang hendak dicapai adalah bagaimana bingkai pemberitaan perempuan dalam Majalah Tempo edisi khusus "Perempuan-Perempuan Penembus Batas"?

\section{TINJAUAN PUSTAKA}

\subsection{Ideologi Media Massa}

Kecenderungan atau perbedaan setiap media dalam memproduksi informasi kepada khalayak dapat diketahui dari pelapisan-pelapisan yang melingkupi institusi media. Pamela Shoemaker dan Stephen D. Reese membuat model "hierarchy of influence". 


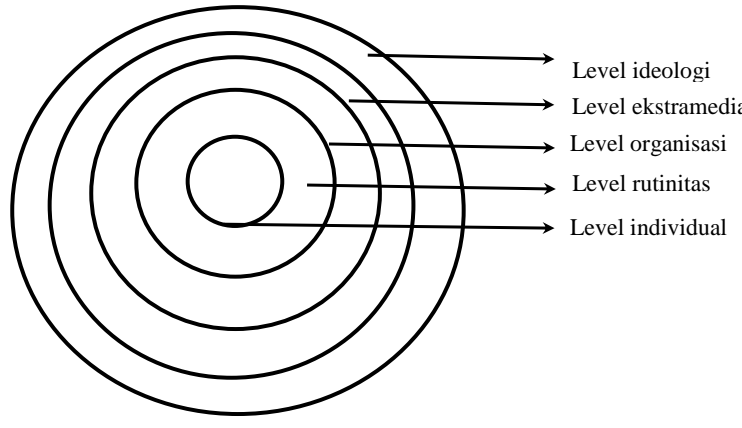

(Sumber: Shoemaker dan Reese, 1996, p. 106)

1. Pengaruh individu-individu pekerja media. Diantaranya adalah karakteristik pekerja komunikasi, latar belakang personal dan profesional.

2. Pengaruh rutinitas media. Apa yang dihasilkan oleh media massa dipengaruhi oleh kegiatan seleksi-seleksi yang dilakukan oleh komunikator, termasuk tenggat (deadline) dan rintangan waktu yang lain, keterbatasan tempat (space), struktur piramida terbalik dalam penulisan berita dan kepercayaan reporter pada sumber-sumber resmi dalam berita yang dihasilkan.

3. Pengaruh organisasional. Salah satu tujuan yang penting dari media adalah mencari keuntungan materiil. Tujuan-tujuan dari media akan berpengaruh pada isi yang dihasilkan.

4. Pengaruh dari luar organisasi media. Pengaruh ini meliputi lobi dari kelompok kepentingan terhadap isi media, pseudoevent dari praktisi public relations dan pemerintah yang membuat peraturanperaturan di bidang pers.

5. Pengaruh ideologi. Ideologi merupakan sebuah pengaruh yang paling menyeluruh dari semua pengaruh. Ideologi di sini diartikan sebagai mekanisme simbolik yang menyediakan kekuatan kohesif yang mempersatukan di dalam masyarakat (Sobur, 2000, p. 138-139).

Sederhananya, ideologi dapat diartikan sebagai politik penandaan atau pemaknaan. Pandangan inilah yang disebut ideologi karena melihat peristiwa dengan kacamata atau pandangan tertentu, yang di dalamnya terdapat proses melihat dan menandakan dengan menggunakan titik lihat tertentu (Eryanto, 2007, p. 130-131). Media, dalam proses pembuatan berita, tidak pernah lepas dari ideologi. Proses kerja pembentukan dan produksi berita bukanlah sesuatu yang netral, melainkan ada bias ideologi yang secara sadar atau tak sadar tengah dipraktikkan oleh wartawan (Eriyanto, 2007, p. 136).

\subsection{Berita sebagai Agen Konstruksi}

Berita bersifat subjektif dan merupakan produk dari konstruksi dan pemaknaan atas realitas. Hasil kerja jurnalistik tidak dapat dinilai dengan menggunakan standar yang rigid. Opini tidak dapat dihilangkan karena ketika meliput, wartawan melihat dengan perspektif dan pertimbangan subjektif (Eriyanto, 2007, p. 27).

\subsection{Perempuan dalam Media}

Konstruksi perempuan dalam berita di media menunjukkan kecenderungan bahwa perempuan masih dianggap sebagai objek yang dieksploitasi keperempuanannya. Terlihat jelas dalam tayangan berbagai iklan, perempuan seringkali ditampilkan secara seronok sehingga mempertegas peran seksinya. Dengan kata lain, media kebanyakan menganggap perempuan sebagai komoditas (barang dagangan). Dalam berbagai surat kabar, perempuan juga masih belum mengalami kesetaraan sebagaimana yang mereka perjuangkan selama ini. Berita mengenai isu perempuan dan pemberdayaan tidak berjalan secara kontinyu, tetapi mengarah pada peristiwa tertentu, misalnya Hari Kartini dan Hari Ibu. Selain itu, berita mengenai perempuan lebih banyak mengenai hal insidental tentang ketidakberdayaan perempuan, seperti kasus penganiayaan tenaga kerja wanita (TKW), perdagangan perempuan, dan lain sebagainya. Pemberitaan perempuan dalam surat kabar pada umumnya juga masih bias gender. Faktor utamanya adalah ideologi yang bersumber dari budaya patriarki yang dimiliki pekerja pers, yang masih didominasi oleh laki-laki. Faktor kedua, adanya kemungkinan belum dipahaminya konsep dan isu gender oleh para pekerja pers yang menyangkut perspektif dari wartawan atau editor media (Joko Sutarso, 2012, p. 13).

\subsection{Perempuan dan Pekerjaan dalam Budaya Patriarki}

Perempuan Indonesia, dalam sejarahnya pun diwarnai pergerakan melawan tekanan. Perempuan menciptakan gerakan-gerakan untuk membebaskan diri dari kotak stereotipe bentukan masyarakat yang cenderung memarginalkan perempuan. Budaya masyarakat Indonesia yang cenderung patriarki, ditambah dengan tatanan Orde Baru selama lebih dari 30 tahun, melestarikan pandangan subordinasi pada perempuan (Murniati, 2004, p.157). Namun seiring berkembangnya modernisasi dan industrialisasi, peluang perempuan dalam dunia profesional juga mengalami peningkatan. Keahlian-keahlian untuk masuk dalam bidang-bidang tertentu juga memungkinkan perempuan untuk bekerja dalam bidang-bidang publik. Namun tak dapat dipungkiri bahwa apresiasi kerja terhadap perempuan masih disepelekan berkaitan dengan stereotipe. Meski masuk dalam pekerjaan profesional, peran perempuan nyatanya masih sering dikategori- 
kan sebagai pembantu seperti sekretaris atau asisten manajer yang muncul di belakang pekerja utama berada (Murniati, 2004, p. 77).

Kedudukan yang tidak setara ini terbentuk karena pandangan bahwa perempuan berada pada posisi subordinat. Berbagai pembenaran dilakukan untuk menjunjang pandangan tersebut sehingga seolah-olah pandangan itu benar dan tidak dapat diubah. Dampaknya, posisi laki-laki selalu memimpin, dan perempuan selalu dipimpin. Dasar relasi yang timpang ini ternyata berlaku dalam setiap aspek kehidupan bermasyarakat dan disebut sebagai biner patriarki. Singkatnya, hubugan biner antara laki-laki dan perempuan, posisinya yang selalu vertikal, kurang lebih bicara mengenai siapa yang menguasai dan dikuasai (Muniarti, 2004, p. 79).

Pengertian sebutan profesional adalah orang yang mendapatkan gaji dari hasil kerjanya (berdasarkan keahlian). Meski peran perempuan dalam dunia kerja seringkali dipandang subordinat yang cenderung memperoleh pelecehan dan tindak kekerasan, tidak relevan jika memandang tugas perempuan 'pembantu' dianggap rendah. Asal mula pekerjaan ini muncul justru karena seseorang atau lembaga merasa tidak mampu menyelesaikan pekerjaannya sendiri. Pada era perkembangan modern, profesionalisme tidak dapat dinilai berdasarkan seksis tetapi atas dasar kemampuan seseorang. Pada hakikatnya, perempuan dan laki-laki memiliki hak dan martabat yang sama, yakni sebagai manusia yang utuh, individu yang merdeka, dan bebas menentukan pilihannya (Murniati, 2004, pp. 80-81).

Menurut Bhasin, patriarki secara harfiah berarti kekuasaan bapak atau "patriarkh (patriarch)". Istilah ini, secara lebih umum digunakan untuk menyebut kekuasaan laki-laki, hubungan kuasa dengan apa lakilaki menguasai perempuan, dan untuk menyebut sistem yang membuat perempuan tetap dikuasai melalui bermacam-macam cara (1996, p.1). Indonesia, merupakan salah satu negara yang menggunakan sistem budaya patriarki. Budaya patriarki menempatkan posisi perempuan kurang memperoleh akses terhadap pendidikan, pekerjaan, serta pengambilan keputusan. Hal ini juga terwujud dengan adanya kebijakan pemerintah yang tertuang dalam berbagai peraturan yang tidak berkeadilan gender begitu pula dalam dunia pendidikan yang menempatkan laki-laki menjadi pemimpin sedangkan anak perempuan akan menjadi ibu rumah tangga (Lestari, 2015, p.73). Dalam sistem ini, melekat ideologi yang menyatakan bahwa laki-laki lebih tinggi daripada perempuan, bahwa perempuan harus dikontrol oleh laki-laki dan bahwa perempuan adalah bagian dari milik laki-laki (Bhasin, 1996, p.4). Laki-laki menjadi pemegang kontrol utama dalam masyarakat, sedangkan perempuan tidak memiliki hak pada wilayah umum dalam masyarakat seperti bidang ekonomi, sosial, politik, dan psikologi, bahkan termasuk di dalamnya, pernikahan (Sakina, 2017, p. 72).

\subsection{Framing}

Gagasan mengenai framing, pertama kali dilontarkan oleh Beterson tahun 1955. Mulanya, frame dimaknai sebagai struktur konseptual atau perangkat kepercayaan yang mengorganisir pandangan politik, kebijakan, dan wacana, serta yang menyediakan kategori-kategori standar untuk mengapresiasi realitas (Sudibyo dalam Sobur, 2004, p. 161). Konsep ini kemudian dikembangkan lebih jauh oleh Goffman pada 1974, yang mengandaikan frame sebagai kepingan-kepingan perilaku (stripe of behavior) yang membimbing individu dalam membaca artikel. Menurut Eriyanto (2007, p. 66), framing adalah pendekatan untuk melihat bagaimana realitas dibentuk dan dikonstruksi oleh media. Proses pembentukan dan konstruksi realitas itu, hasil akhirnya adalah adanya bagian tertentu dari realitas yang lebih menonjol dan lebih mudah dikenal.

\section{METODE}

\subsection{Konseptualisasi Penelitian}

Penelitian ini merupakan penelitian kualitatif deskriptif dengan metode analisis framing. Peneliti akan mencari bingkai dalam pemberitaan mengenai perempuan bekerja dalam Majalah Tempo edisi khusus "Perempuan-Perempuan Penembus Batas". Metode analisis framing dapat menunjukkan penonjolan atau penyembunyian fakta dalam realita yang dituliskan dalam berita.

\subsubsection{Subjek Penelitian}

Sasaran penelitian ini adalah Majalah Tempo edisi khusus "Perempuan-Perempuan Penembus Batas", berisi 10 berita sosok-sosok perempuan pilihan yang mewakili sembilan bidang.

Unit analisis data dalam penelitian ini adalah pemberitaan mengenai sosok perempuan karier pilihan Majalah Tempo, edisi April 2016. Peneliti akan mengamati pemberitaan tersebut dengan cara menganalisis, analisis framing model Pan dan Kosicki. Dalam sepuluh artikel yang akan dianalisis, terdapat headline, lead, deskripsi $5 \mathrm{~W}+1 \mathrm{H}$, diksi, ilustrasi, foto, dan lain-lain. Setiap bagian berita tersebut akan dianalisis dan diinterpretasi secara mendalam. 


\subsubsection{Analisis Data}

Peneliti akan menganalisis data dengan melakukan pendalaman dalam teks sesuai dengan konteks dan melakukan interteks yang menunjang. Dengan menggunakan metode analisis framing miliki Pan \& Kosicki, peneliti akan menganalisis sepuluh berita tentang perempuan dalam Majalah Tempo edisi khusus "Perempuan-Perempuan Penembus Batas". Elemen yang digunakan untuk menunjang penelitian ini adalah struktur sintaksis, skrip, tematik, dan retoris. Struktur sintaksis dapat dijelaskan sebagai cara wartawan menyusun fakta. Berisi unit yang diamati yakni headline, lead, latar informasi, kutipan sumber, pernyataan, dan penutup. Dalam pengertian umum, sintaksis adalah susunan kata atau frase dalam kalimat. Elemen dalam sintaksis memberi petunjuk yang berguna tentang bagaimana wartawan memaknai peristiwa dan hendak kemana berita akan dibawa. Struktur skrip akan melihat kelengkapan informasi dalam berita, yakni cara wartawan mengisahkan fakta, sementara struktur tematik akan membahas mengenai detail, koherensi, bentuk kalimat, dan kata ganti yang akan menunjukkan bagaimana cara wartawan menuliskan fakta. Terakhir, struktur retoris, bicara mengenai cara wartawan menekankan fakta dengan melihat pada leksikon, idiom dan penggunaan foto.

\section{TEMUAN DATA}

\subsection{Struktur Sintaksis}

Elemen sintaksis memberi petunjuk yang berguna tentang bagaimana wartawan memaknai peristiwa dan hendak kemana berita tersebut akan dibawa (Eriyanto, 2007, p. 257). Skema berita yang tersusun menunjukkan relevansi bahwa para tokoh perempuan tersebut memang bekerja di bidang yang patriarkis karena dalam setiap bidang terdapat tokoh laki-laki yang menjadi narasumber pendukung. Hal ini sesuai dengan lead utama dari edisi khusus perempuan, bahwa bidang pekerjaan yang dibahas bersifat patriarkis.

Empat puluh lima perempuan pilihan ini menunjukkan perjuangan di sejumlah bidang yang sering kali patriarkis. Mengambil jalan berisiko, terjal dan sepi.

Para tokoh perempuan juga diceritakan memiliki peran penting, hasil kerja yang berdampak, dan sifatsifat mulia. Wartawan juga menonjolkan kegigihan, sifat pantang menyerah dari masing-masing tokoh perempuan meski mengalami kesulitan dalam pekerjaannya. Wartawan juga mengkonstruksi perempuan memiliki sifat suka berbagi, baik hati dan rendah hati meski memiliki ilmu, jabatan dan posisi. Dilihat dari skema pada struktur sintaksis, peneliti menemukan bahwa wartawan mendukung sosok-sosok perempuan bekerja pada ranah publik. Merangkai dari temuan-temuan sebelumnya, maka Majalah Tempo membingkai perempuan pilihan sebagai seorang yang berprestasi di bidang masing-masing namun memiliki sifat-sifat tertentu seperti rendah hati, baik hati, dan rela menolong orang lain.

\subsection{Struktur Skrip}

Melalui struktur skrip, peneliti menemukan bahwa unsur who dan what, lebih ditonjolkan oleh Majalah Tempo dalam edisi khusus perempuan. Unsur who ditonjolkan bukan karena tokoh yang diliput adalah orang terkenal (prominence), tokoh dalam berita memang tidak harus selalu figur yang dikenal publik, tetapi siapa saja yang terlibat dalam suatu peristiwa yang unik (Djuraid, 2012, p.25-26). Majalah Tempo mengangkat para tokoh (who) dalam rangkaian berita ini untuk menekankan pada kontribusinya atas peristiwa (what), Majalah Tempo juga memberikan alasan (why) mengapa para tokoh melakukan hal tersebut untuk memberikan kisah yang dapat diteladani dan menginspirasi pembaca.

Unsur who dalam rangkaian berita ini merupakan tokoh-tokoh yang bukan orang-orang di depan layar yang dikenal akrab oleh pembaca. Sedangkan unsur what merupakan hal yang dikerjakan oleh para tokoh tersebut. Unsur why, dimunculkan sebagai suatu kondisi yang membuat para tokoh berada di posisi yang sekarang. Jika ketiga unsur tersebut diramu, peneliti menemukan bahwa para tokoh yang ditulis oleh Majalah Tempo adalah sosok yang inspiratif. Majalah Tempo menekankan who sebagai orangorang yang memiliki kontribusi yang besar pada what, unsur why memberikan penguatan alasan bahwa yang dilakukan para perempuan tersebut merupakan sebuah bentuk perjuangan kebenaran untuk menolong orang lain, bukan demi dirinya sendiri. Meski berada dalam bidang yang dikatakan patriarkis, dari unsur skrip, peneliti menemukan bahwa Majalah Tempo memberikan konstruksi kepada perempuan bekerja berupa sebuah tujuan untuk menolong kondisi sosial kembali ideal. Majalah Tempo, sedang menggiring pembaca untuk menerima perspektif bahwa perempuan yang bekerja di bidang-bidang publik tidak perlu dipermasalahkan, justru patut diapresiasi karena melakukan perjuangan demi orang lain.

\subsection{Struktur Tematik}

Melalui sktruktur tematik, peneliti menemukan bahwa Majalah Tempo mengkonstruksi perempuan sebagai orang-orang yang menginspirasi di bidang masing-masing. Bagi Pan dan Kosicki, struktur tematik mirip seperti pengujian hipotesis: peristiwa yang diliput, sumber yang dikutip, dan pernyataan yang diungkapkan digunakan untuk membuat dukungan 
yang logis bagi hipotesis yang dibuat (Eriyanto, 2007, p.262). Majalah Tempo cenderung menggunakan kalimat aktif dalam memberitakan sosok-sosok perempuan tersebut. Kalimat aktif memiliki struktur kalimat yang menerangkan bahwa subjek berperan dalam predikat. Dari penulisan ini, Majalah Tempo menempatkan sosok-sosok perempuan sebagai orangorang yang bertindak sebagai pelaku atau pemeran.

Majalah Tempo melalui sktruktur tematik, telah mengkonstruksi perempuan sebagai sosok-sosok yang memiliki dampak dan peran penting, berani melakukan perlawanan secara rasional, berprestasi, tidak mudah menyerah, dan membutuhkan dukungan dalam menjalani kehidupan terutama dari keluarga.

\subsection{Struktur Retoris}

Dari sepuluh kisah perempuan-perempuan yang diberitakan Majalah Tempo, peneliti menemukan beberapa kata yang sering digunakan atau diulang. Pengulangan kata merupakan salah satu cara wartawan menekankan suatu makna. Demikian pula dengan pemilihan dan penggunaan kata-kata tertentu untuk menandai atau menggambarkan peristiwa. Pemilihan kata ini dapat menunjukkan secara ideologis, bagaimana pemaknaan seseorang terhadap fakta/realitas. Hal ini disebut sebagai leksikon, salah satu perangkat framing dalam struktur retoris (Eryanto, 2007, 256).

Peneliti menemukan adanya perbedaan signifikan antara Majalah Tempo dengan media lain dalam mengkonstruksi perempuan. Sejauh pengamatan peneliti, biasanya media akan mengkonstruksi perempuan karier dalam citra yang buruk karena terpengaruh ideologi patriarki. Perempuan dalam media distereotipekan dalam pandangan yang merugikan: pasif, didominasi, bergantung pada laki-laki, menerima keputusan yang dibuat oleh laki-laki dan terutama melihat dirinya sebagai objek seks (Ibrahim, 1998, p. 107). Pandangan patriarki juga mengharuskan perempuan untuk hanya fokus pada urusan domestik seperti mengurus anak dan urusan rumah tangga. Berkaitan dengan hal itu, Majalah Tempo tidak melihat perempuan profesional dalam pandangan yang sesuai dengan stereotipe tersebut.

Malahan, Majalah Tempo mengkonstruksi perempuan sebagai mitra kerja yang profesional seperti hasil analisis sebelumnya. Kecenderungan setiap media dalam memproduksi informasi kepada khalayak dapat diketahui dari pelapisan yang melingkupi institusi media (Sobur, 2000, p. 138-139). Model hierarchy of influence milik Shoemaker dan Reese, dapat menjelaskan perbedaan pandangan antara
Majalah Tempo dengan media lain dalam mengkonstruksi perempuan. Peneliti melihat bahwa hal yang mempengaruhi perbedaan pandangan terletak pada pengaruh organisasional. Pengaruh organisasional memiliki tujuan-tujuan tertentu yang akan mempengaruhi isi berita. Melihat pada waktu Majalah Tempo edisi khusus perempuan ini diterbitkan, yaitu bulan April 2016, maka rangkaian berita ini dibuat untuk memperingati Hari Kartini sekaligus menyambut ulang tahun ke-45 Majalah Tempo.

Pengaruh organisasional juga mengarahkan wartawan menggunakan idiom yang mengkonstruksi makna. Peneliti menemukan beberapa idiom seperti "mengejar mimpi", "keluarga kecil", "terkadang bisa tegas tapi suaranya juga bisa lembut", "tanpa mengenal lelah", "naluri menolong Leonika mendidih". Idiom "terkadang bisa tegas tapi suaranya juga bisa lembut" merangkum sifat tokoh yang mampu menempatkan diri sebagai perempuan yang lembut meski berada dalam dunia kerja publik. Idiom "naluri menolong Leonika mendidih" juga digunakan untuk menggambarkan sifat tokoh yang selalu ingin membantu, sebagaimana seperti dorongan hati yang alami. Penggunaan kata 'mendidih' dapat diartikan sebagai sifat yang meluap-luap. Idiom "keluarga kecil" digunakan wartawan untuk menggambarkan bahwa dalam bekerja, tokoh perempuan juga membentuk ikatan relasi dalam lingkungan pekerjaannya karena relasi bagi perempuan merupakan hal yang penting.

\section{ANALISIS DAN INTERPRETASI}

Dalam penelitian ini terdapat enam konstruksi dalam pemberitaan perempuan dalam Majalah Tempo edisi khusus "Perempuan-Perempuan Penembus Batas":

1. Perempuan sebagai agen perubahan

Agen perubahan merujuk pada aksi nyata para perempuan dalam merespon situasi di sekitarnya, untuk menjadikannya ideal kembali. Kisah-kisah inspiratif dari seluruh tokoh ini mengandung nilainilai yang penting seperti kepekaan merespon masalah di sekitar, keinginan untuk menolong orang lain, hingga aksi nyata yang harus dilakukan. Keempat tokoh tersebut merupakan perwakilan dari sepuluh tokoh yang menjadi agen perubahan dalam bidang masing-masing. Majalah Tempo menunjukan bahwa para perempuan ini tidak hanya bekerja, namun memberikan perubahan yang penting dan nyata melalui bidang masingmasing.

2. Perempuan sebagai sosok-sosok pejuang

Perempuan dalam pandangan lama ditempatkan sebagai pribadi yang pasrah. Namun dalam rangkaian berita ini, Majalah Tempo justru menempat- 
kan perempuan sebagai orang-orang yang memiliki daya juang tinggi. Majalah Tempo menggambarkan bahwa para perempuan tersebut memperjuangkan idealisme, yaitu dengan mengembalikan keadaan seperti seharusnya melalui masingmasing bidang yang mereka dapat lakukan.

3. Perempuan sebagai orang yang mampu bekerja Menurut pandangan tradisional, perempuan tidak disiapkan untuk berkarier karena fokus utama perempuan adalah bekerja di rumah, melayani suami dan merawat anak. Majalah Tempo, sudah tidak lagi menempatkan perempuan dalam stigma lama yang merugikan, namun mengkonstruksi perempuan sebagai pribadi yang penting bagi kemajuan bangsa. Majalah Tempo juga menonjolkan perempuan sebagai pribadi yang patut diperhitungkan sebagai rekan kerja profesional melalui kisah Sheila yang bermitra dengan tunangannya dalam mengembangkan usaha desain busana.

4. Perempuan membutuhkan dukungan dari relasi yang ada di sekitarnya

Dari sepuluh sosok perempuan yang diberitakan Majalah Tempo, seluruhnya ditemukan membutuhkan dukungan dari pihak luar. Relasi penting bagi perempuan karena salah satu kebutuhan perempuan adalah mendapatkan dukungan.

5. Perempuan terlibat dalam kemajuan bangsa

Dari sepuluh kisah tokoh perempuan yang diberitakan berkarya di bidang masing-masing, didapati bahwa kesepuluh tokoh tersebut memiliki kaitan dengan bidang-bidang dalam Nawacita. Kaitan yang terjadi bukan hanya melalui bidang yang digeluti para perempuan tersebut, tetapi juga latar belakang kisah masing-masing.

6. Perempuan dikonstruksi menurut pandangan feminisme liberal

Dari temuan data, Majalah Tempo memberitakan perempuan memiliki kemampuan bekerja, setara dengan laki-laki, namun juga emosional, dan peka terhadap sekitarnya. Seluruh temuan tersebut mengarah pada pandangan feminisme liberal yang berkeinginan untuk membebaskan perempuan dari peran gender yang oprehesif sebagai atasan atau pembenaran untuk memberikan tempat yang lebih rendah bagi perempuan (Tong, 1998, p.48). Pandangan ini juga mengembangkan tipe kepribadian monoandrogini, yaitu kepribadian yang ideal yang menubuhi sifat gender maskulin dan feminin paling baik (Tong, 1998, p. 51). Menurut Sandra Bem,seorang psikolog, seseorang yang monoandrogin mempunyai kualitas tradisional perempuan yang penuh, yaitu penyayang, pengasih, lembut, sensitif, berkemampuan untuk berhubungan dengan yang lain, dan mampu bekerjasama, dan pada saat bersamaan juga memliki kualitas lakilaki tradisional, yaitu agresif, berkemampuan memimpin, berinisiatif dan mampu bersaing. Dari penjelasan tersebut, jelas terlihat bahwa Majalah Tempo membingkai pemberitaan mengenai sosok-sosok perempuan dalam edisi khusus ini sebagai feminis liberal dengan tipe kepribadian monoandrogini. Pesan yang tonjolkan Majalah Tempo melalui pemberitaan perempuan-perempuan pilihan ini adalah menampilkan sifat ideal perempuan yang mampu bekerja dengan baik, berkemampuan memimpin, mampu bersaing, namun tetap memiliki sifat yang sensitif, lembut, pengasih dan penyayang, serta kemampuan berhubungan (untuk mendapatkan dan memberikan dukungan).

\section{SIMPULAN}

Dari hasil analisis dan intepretasi data yang peneliti lakukan terhadap sepuluh berita dalam Majalah Tempo Edisi Khusus Perempuan, disimpulkan bahwa Majalah Tempo membingkai perempuan dalam pandangan feminisme liberal, yang berkeinginan untuk membebaskan perempuan dari peran gender yang oprehesif sebagai alasan atau pembenaran untuk memberikan tempat yang lebih rendah bagi perempuan. Pandangan ini mempengaruhi penonjolan peristiwa yang diberitakan mengenai perempuan sehingga Majalah Tempo memberikan penekanan dalam kisah sosok-sosok perempuan ini sebagai agen perubahan, memiliki kemampuan bekerja yang baik, sosok pejuang, membutuhkan dukungan, serta menjadi agen perubahan. Pemberitaan perempuan dibingkai demikian sesuai dengan kepribadian yang dikembangkan oleh para aktivis feminisme liberal, yaitu monoandrogini. Kepribadian ini meliputi sifat feminin dan maskulin paling baik yang dimiliki oleh perempuan. Sifat-sifat tersebut adalah penyayang, pengasih, lembut, sensitif, berkemampuan untuk berhubungan dengan yang lain, dan mampu bekerjasama, sekaligus agresif, berkemampuan memimpin, berinisiatif dan mampu bersaing.

\section{DAFTAR PUSTAKA}

Bhasin, K. (1996). Menggugat Patriarki. Yogyakarta: Yayasan Bentang Budaya.

Djuraid, H. (2012). Panduan Menulis Berita. Malang: UPT Penerbitan Universitas Muhammadiyah.

Eryanto. (2007). Analisis Framing. Yogyakarta: LKiS Yogyakarta.

Heryanto, A. (1998). Wanita Korban Pembangunan. In I. S. Ibrahim, Wanita dan Media (pp. 36-40). Bandung: Remaja Rosdakarya. 
Ibrahim, M. (1998). Perempuan dan Komunikasi: Beberapa Catatan Sekitar Citra Perempuan dalam Media. In I. S. Ibrahim, Wanita dan Media (pp. 106-111). Bandung: Remaja Rosdakarya.

Buntarjo, R. I. (2017). Analisis Semiotika Film The Secret Life of Pets. Universitas Pasundan, 6-7.

McQuail, D. (1987). Teori Komunikasi Massa. Jakarta: Penerbit Erlangga.

Murniati, N. P. (2004). Getar Gender. Magelang: Indonesia Tera.
Shoemaker, P. (1996). Mediating the Message: Theories of Influences on Mass Media Content, Second Edition. New York: Longman Publishers USA.

Sobur, A. (2004). Analisis Teks Media. Bandung: PT Remaja Rosdakarya.

Tong, R. (1998). Feminist Thought: Pengantar Paling Komprehensif kepada Aliran Utama Pemikiran Feminis. Yogyakarta: Jalasutra. 